\title{
PERBANDINGAN PENGGUNAAN PLTS DENGAN GENSET \\ DI DESA SOKO KEMBANG KECAMATAN PETUNGKRIYONO \\ KABUPATEN PEKALONGAN \\ I. DITINJAU DARI MORE EFFICIENT PROCESS
}

\author{
Ghoni Musyahar \\ J1. Majapahit 605 \& 304 \\ Semarang Indonesia \\ E-mail : sultandigitalpicture@ymail.com
}

\begin{abstract}
Abstrak
Di Pekalongan, tepatnya di desa Soko Kembang kecamatan Petungkriyono dibuat PLTS sebanyak sekiktar 31 unit. PLTS ini bekerja secara stand alone, dengan sistem SHS. Setiap unit SHS terdiri dari sebuah panel surya $50 \mathrm{Wp}$, tiga buah titik lampu, baterai 70Ah, dan Box Control Unit.Berdasarkan studi lapangan awal, penggunaan SHS sangat bermanfaat dan membantu masyarakat di malam hari terutama pelajar dan ibu-ibu yang memiliki anak kecil, serta membantu warga desa Soko Kembang yang merupakan desa terpencil yang sebelumnya mengandalkan penerangan dari lampuminyak dan genset sewa.

Penggunaan PLTS berdampak terhadap kehidupan ekonomi masyarakat, yang dinilai dari adanya peningkatan ekonomi masyarakat. Hal tersebut dibuktikan dengan payback yang tinggi.
\end{abstract}

Kata kunci : PLTS, More Efficient Process

\section{A. PENDAHULUAN}

\section{Latar Belakang}

Potensi energi surya Indonesia sebesar 4,8 $\mathrm{kWh} / \mathrm{m} 2$,menyebabkan Indonesia berpotensi untuk memanfaatkanenergi surya sebagai sumber energi listrik. Hal ini memungkinkan penyediaan energi listrik tuk daerah-daerahterpencil yang belum dijangkau aliran listrik, melalui sistem photovoltaic dengan cara PLTS terpusat atau SHS. Di Pekalongan, tepatnya di desa Soko Kembang kecamatan Petungkriyono dibuat PLTS sebanyak sekiktar 31 unit. PLTS ini bekerja secara stand alone, dengan sistem SHS. Setiap unit SHS terdiri dari sebuah panel surya $50 \mathrm{Wp}$, tiga buah titik lampu, baterai 70Ah, dan Box Control Unit.Berdasarkan studi lapangan awal, penggunaan SHS sangat bermanfaat dan membantu masyarakat di malam hari terutama pelajar dan ibu-ibu yang memiliki anak kecil, serta membantu warga desa Soko Kembang yang merupakan desa terpencil yang sebelumnya mengandalkan penerangan dari lampu minyak dan genset sewa. PLTS Selain bermanfaat karena dapat mengurangi penggunaan minyak tanah dan solar sebagai bahan bakar lampu penerangan, penggunaan SHS lebih aman, mudah digunakan, dan memiliki kualitas penerangan yang lebih baik untuk kegiatan di malam hari. Energi listrik yang dihasilkan SHS, juga memberikan masyarakat sarana hiburan, pendidikan,dan informasi dengan adanya TV, radio, dan handphone.Pada saat ini, 65,83\% SHS tidak dapat beroperasi karena rusaknya beberapa komponen, seperti panel surya, fitting dan aki. Kurangnya pengetahuan masyarakat tentang sistem SHS dan cara memperbaiki SHS, menyebabkan SHS yang tidak berfungsi pada akhirnya didiamkan begitu saja, dan masyarakat lebih memilih kembali menggunakan lampu minyak sebagai sumber penerangan ataupun genset sewa. Dengan tidak berfungsinya SHS berpengaruh terhadap kehidupan sosial dan ekonomi masyarakat yang menggantungkan hidupnya dari ketrampilan merajut, seperti payet, menyulam dan lain-lain yg dilakukan dalam kegiatan di malam hari. Berdasarkan permasalahan di atas, maka dalam penelitian ini dibahas mengenai dampak ekonomi dan sosial penggunaan PLTS sebagai listrik pedesaan terhadap masyarakat desa. Untuk menyelesaikan permasalahan tersebut, dilakukan analisis dengan mencari hubungan dari beberapa aspek, yaitu teknis, ekonomi dan sosial, dengan menggunakan metode observasi, kuesioner dan wawancara. Aspek sosial yang dibahas meliputi pendidikan, kesehatan, keamanan, hiburan, dan keagamaan.

\section{Tujuan}

Tujuan dari penulisan ini adalah untuk mengetahui dan menyampaikan bahwa penggunaan PLTS lebih menguntungkan dari pada genset jika ditinjau dari more efficient process.

\section{B. LANDASAN TEORI}

\section{PLTS}

Pembangkit Listrik Tenaga Surya (PLTS) adalah pembangkit yang mengkonversikan energi foton dari surya menjadi energi listrik. Konversi ini terjadi pada panel surya yang terdiri dari sel-sel photovoltaik. Selsel ini terdiri dari lapisan-lapisan tipis dari silikon ( $\mathrm{Si}$ ) murni dan bahan semi konduktor lainnya. PLTS 
memanfaatkan energi surya langsung untuk menghasilkan listrik DC yang kemudian dapat diubah menjadi listrik AC apabila diperlukan, dengan bantuan inverter. Pemanfaatan energi surya sebagai pembangkit listrik, umumnya terdiri dari beberapa komponen, yaitu panel surya, charge controller, baterai, kabel dan inverter jika diperlukan.

SHS merupakan salah satu bentuk aplikasi dari PLTS. Pemanfaatan tenaga matahari untuk pembangkitan energi listrik ini sudah dilakukan sejak awal tahun 80-an dan masih terbatas pada sistem berdaya kecil. Sistem ini biasanya memiliki kapasitas antara 25-50 Wp, sehingga kemampuannya dalam mencatu peralatan dengan beban yang besar sangat terbatas. Sistem ini terdiri dari panel surya, baterai, charge controller, dan tiga buah titik lampu. SHS umumnya digunakan oleh masyarakat pedesaan yang belum dijangkau dengan jaringan listrik PLN. Penduduk desa menggunakan SHS sebagai lampu penerangan untuk menggantikan lampu tradisional yang berbahan bakar minyak tanah atau solar. Pemanfaatan SHS ini tentu sangat bermanfaat karena dapat mengurangi penggunaan minyak tanah dan solar, mengurangi emisi karbon, lebih aman, lebih mudah, dan memiliki kualitas penerangan yang lebih baik untuk aktivitas di malam hari, seperti belajar dan kegiatan produktif lainnya. Dengan adanya SHS juga memungkinkan masyarakat untuk menikmati peralatan elektronik, seperti radio dan TV sebagai sarana hiburan, pendidikan, dan informasi. Berdasarkan data tahun 2009, jumlah kapasitas PLTS/SHS telah mencapai 13,5 MWp. Namun, perkembangan pemasangan SHS di Indonesia ini terbilang cukup lambat karena masih sangat tergantung dari program pemerintah, sehingga hingga saat ini total kapasitas daya terpasangnya dalam bauran energi nasional masih sangat kecil. Akan tetapi dengan adanya rencana pemerintah tentang diversifikasi energi nasional, maka PV memiliki prospek yang sangat bagus di masa mendatang untuk mendukung energi mix yang akan dicapai pada tahun 2025 .

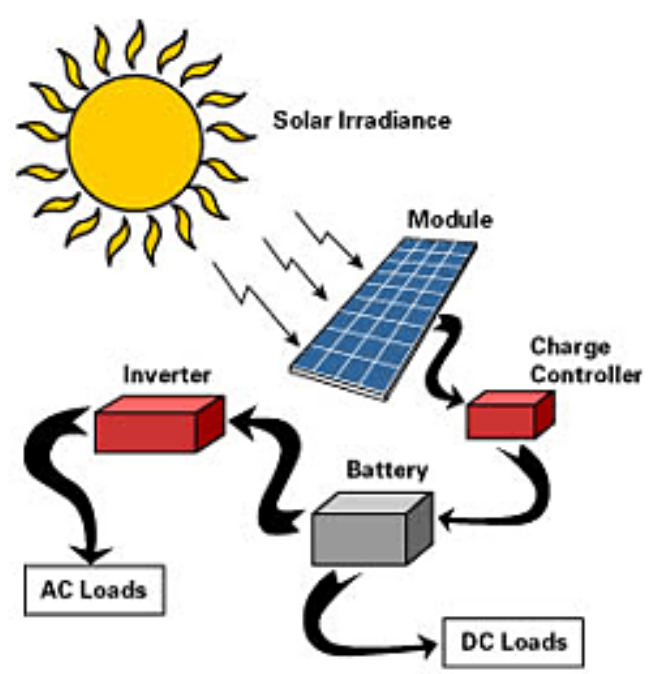

Gambar 1. Sistem kerja PLTS

\section{Listrik Pedesaan}

Pembangunan listrik pedesaan merupakan penugasan pemerintah untuk memberikan listrik kepada masyarakat pedesaan. Kebijakan yang diambil oleh Direktorat Jendral Ketenagalistrikan (DJK) dan PLN dalam pembangunan listrik desa adalah untuk memenuhi rasio elektrifikasi $80 \%$ dan desa berlistrik 98,9\% di tahun 2014. Pembangunan ini sesuai dengan RPJM Departemen ESDM 2010-2014, yaitu melistriki desa baru maupun lama yang sebagian dari dusun tersebut belum berlistrik, daerah terpencil dan daerah perbatasan, serta dimungkinkan untuk pengadaan hybrid PLTS dan hybrid PLTB yang sistemnya terhubung dengan grid PLN. Secara umum tujuan dari pelistrikan daerah pedesaan, merupakan usaha dalam memberikan listrik kepada desadesa, terutama untuk negara berkembang. Dapat disusun beberapa faktor penting dalam pelaksanaannya, yaitu sebagai berikut.

1) Penggunaan listrik untuk tujuan produktif (ekonomi) Fokus pelistrikan desa pada umumnya diletakan pada usaha-usaha untuk membangkitkan atau meningkatkan kegiatan-kegiatan produktif masyarakat. Penggunaan listrik bisa untuk melakukan kegiatan seperti pompa irigasi, industri pedesaan, bengkel kecil, peralatan pertanian, fasilitas pendingan, dll. Peningkatan kegiatan produktif ini pada akhirnya akan meningkatkan jumlah lapangan pekerjaan, produksi pertanian, dan jasa-jasa lainnya, sehingga bisa meningkatkan pendapatan penduduk.

2) Manfaat sosial

Program misi sosial dimaksudkan untuk membantu kelompok masyarakat tidak mampu, menjaga kelangsungan dalam upaya perluasan akses pelayanan listrik pada wilayah yang belum terjangkau listrik, dan mendorong pembangunan dan pertumbuhan ekonomi serta meningkatkan kesejateraan rakyat pedesaan. Manfaat sosial ini pada umumnya berpengaruh secara jangka panjang, antara lain seperti, peningkatan kesempatan membaca dan belajar, peningkatan taraf kesehatan rakyat, bahkan dengan adanya tenaga listrik mempunyai pengaruh yang baik terhadap hasil-hasil keluarga berencana, karena pada waktu malam hari dapat diisi dengan kegiatan sosial, serta memudahkan dan mempercepat masyarakat pedesaan memperoleh informasi dari media elektronik dan media komunikasi lainnya. Dilaporkan, dari hasil penelitian bahwa dengan adanya penerangan listrik pada umumnya dapat meningkatkan keamanan, sehingga masyarakat merasa terjamin keamanannya. Hal-hal tersebut, secara keseluruhan akan meningkatkan percaya diri masyarakat yang pada gilirannya dalam jangka panjang akan membuka jalan kepada pengembangan berbagai bakat yang ada untuk inovasi dan kewirausahaan.

Dengan adanya energi listrik atau dengan mempergunakan energi listrik pada pedesaan, bila dipergunakan sebaiknya, tepat, layanan tenaga listrik 
dapat diandalkan, terjangkau dan dapat diakses oleh masyarakat, maka dapat memecah lingkaran setan kemelaratan pada masyarakat. Pelistrikan suatu desa tidak dapat dilakukan begitu saja, melainkan harus disertai dengan persiapan yang baik. Jika tidak maka akan dapat menimbulkan beberapa persoalan, seperti penggangguran dan perilaku konsumtif masyarakat. Hal ini tentu kedepannya akan berdampak negatif terhadap masyarakat. Oleh karena itu, usaha listrik masuk desa perlu dilakukan dengan persiapan yang baik. Aspek kepemilikan dan pengetahuan terhadap teknologi juga tidak bisa lepas dari perhatian. Karena dengan adanya rasa kepemilikan maka masyarakat akan lebih merasa memiliki, menjaga, dan merawat teknologi tersebut. Begitu juga dengan adanya pengetahuan terhadap teknologi, dimana akan dapat membekali dan membantu masyarakat untuk mengetahui bagaimana peralatan itu bekerja dan memperbaiki jika terjadi kerusakan. Dengan didasari rasa ini, maka sistem dapat dipergunakan lebih lama dan secara tidak langsung dapat mengurangi penggunaan BBM sebagai sumber bahan bakar lampu tradisonal.

\section{METODELOGI}

Metodologi dilakukan adalah melakukan survey ke PLTS desaSokokembang yang dilanjutkan dengan mencari referensi yang berkaitan dengan PLTS dan genset seta more efficient process. Langkah selanjutnya yaitu membandingkan keuntungan yang di dapat dari dua pembangkit tersebut.

\section{HASIL DAN PEMBAHASAN} solar sel

Perbandingan sebelum dan sesudah menggunakan

Sebelum pemerintah membuatkan unit PLTS, masyarakat setempat menggunakan fasilitas listrik dengan cara menyewa genset diesel. Tarif sewa per-rumah Rp.90.000,- selama 10 jam ( jam 6 sore sampai jam 5 pagi). Dan hanya dibatasi daya 50 watt saja. Dan jika dihitung pengeluaran per-harinya adalah :

90.000/30=Rp. 3000,-

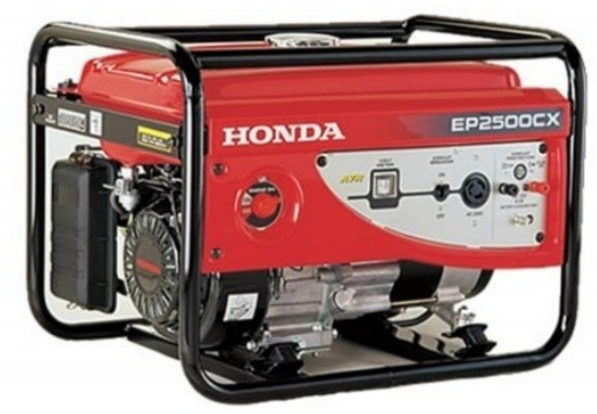

Gambar 2. Genset

Jika menggunakan PLTS masyarakat sudah tidak membayar sewa genset lagi, hanya saja harus masyarakat harus merawat unit PLTS masing-masing. Yang sering diganti adalah baterai. Efektif penggunaannya sekitar 2 tahun ( 2x 365 hari ) atau 730 hari. Jika harga baterai Rp.
400.000,- maka dalam 1 hari warga mengeluarkan uang sebesar Rp. 547,-. Dan tanpa di batasi waktu pemakaian, karena sumber energinya gratis (matahari).

\section{More Efficient Process}

Penggunaan PLTS didaerah terpencil (Soko Kembang) sangat tepat sekali dibandingkan menggunakan tenaga genset. Karena dengan menggunakan PLTS akan terjadi proses yang paling efisien. Untuk lebih jelasnya bisa dilihat di tabel berikut.

Tabel 1. More Efficient Process Genset dan PLTS

\begin{tabular}{|c|c|c|c|c|}
\hline $\begin{array}{l}\text { Media } \\
\text { Pembangkit }\end{array}$ & $\begin{array}{l}\text { Daya } \\
\text { yang } \\
\text { diperoleh } \\
\text { per- } \\
\text { rumah }\end{array}$ & $\begin{array}{l}\text { Biaya yang } \\
\text { dikeluarkan } \\
\text { tiap hari } \\
\text { (Rupiah) }\end{array}$ & $\begin{array}{l}\text { Jumlah jam } \\
\text { penggunaan } \\
\text { tiap hari } \\
\text { (jam) }\end{array}$ & $\begin{array}{l}\text { Pencemaran } \\
\text { lingkungan }\end{array}$ \\
\hline GENSET & $50 \mathrm{Watt}$ & 3000 & 10 & $\begin{array}{l}\text { Ada (gas } \\
\text { CO2) }\end{array}$ \\
\hline PLTS & $50 \mathrm{Wp}$ & 547 & 24 & Tidak ada \\
\hline
\end{tabular}

\section{Perhitungan Pay Back}

Jika dalam sebulan keuntungan yang diperoleh jika menggunakan PLTS adalah :

$3000-547=$ Rp. 2453,- tiap harinya

Jika dalam sebulan adalah:

2453 × $30=$ Rp. 73590,-

Jika dalam setahun adalah:

73590 x $12=$ Rp. 883.080,-

Angka yang sangat fantastis, karena dalam setahun bisa disimulasikan dengan kedua perbandingan akan terjadi payback sebesar Rp. 883.080,-

\section{Efek PLTS bagi lingkungan hidup}

PLTS sangat ramah lingkungan karena tidak ada pembuangan zat-zat berbahaya. Hanya memanfaatkan energi pancaran sinar matahari belaka.

\section{E. KESIMPULAN}

Berdasarkan hasil dan pembahasan yang telah dilakukan, maka dapat dikemukakan beberapa simpulan:

1) Penggunaan PLTS berdampak terhadap kehidupan ekonomi masyarakat, yang dinilai dari adanya peningkatan ekonomi masyarakat. Hal tersebut dibuktikan dengan payback yang tinggi.

2) Penggunaan PLTS berdampak terhadap kehidupan sosial masyarakat, yang dinilai dari adanya peningkatan dalam bidang pendidikan, kesehatan, keamanan, hiburan, dan keagamaan. 


\section{Daftar Pustaka}

[1] Abdulkadir, A. 2011. Teknologi Pembangkit Listrik Ramah Lingkungan: Seri Ketenagalistrikan Jidil 1. Bandung: ITB.

[2] Boxwell, M. 2009. Solar Electricity Handbook. UK : Code Green Publishing.

[3] Dulinger, B., Reinders, A. Toxopeus, M. 2010. Enviromental Benefits Of PV Powered Lighting Products For Rural Area In South East Asia : A Life Cycle Analysis With Geographic Allocation. Nehterlands: Dept. of Design, Production \& Manage., Univ. of Twente, Enschede.

[4] EBTKE. 2011. Kapasitas Terpasang PLTS/SHS. Jakarta: Dirjen Energi Baru Terbarukan dan Konversi Energi.

[5] Hutchinson, L. 2011. Solar Power. South Africa: Linkd Environmental Service.

[6] Kadir,A. 2010. Energi: Sumber Daya, Inovasi, Tenaga Listrik dan Potensi Ekonomi, edisi 3. Jakarta: Universitas Indonesia.

[7] Khan, A.H., Khan, M.F., Mostofa, R. 2012. Solar PV As An Effective Alternative To Oil Based Lamp In The Rural Bangladesh. Bangladesh: EEE Dept., United Int. Univ., Dhaka.

[8] Kumara, I N. S. 2010. Pembangkit Listrik Tenaga Surya (PLTS) Skala Rumah Tangga Urban dan Ketersediaannya di Indonesia, Vol: 9 No.1 hal 71. Bali: Universitas Udayana.

[9] RUPTL. 2011.Rencana Usaha Penyediaan Tenaga Listrik PT PLN (Persero) 2011 - 2020. Jakarta: Kementrian Energi dan Sumber Daya Mineral.

[10]RUKN. 2012. Rencana Umum Ketenagalistrikan Nasional 2012-2031. Jakarta: Kementrian Energi dan Sumber Daya Mineral.

[11] Quaschning, V. 2005. Understanding Renewable Energy System. London: Earthscan Publications Ltd.

[12] Timilsina, G. R., Kurdgelashvili, L. Narbel, P. A. 2011. A Review of Solar Energy: Market, Economics and Policies. The World Bank Development Research Group Environment and Energy Team. 